\title{
The Impact of Mobile Banking on Financial Inclusion In Zimbabwe: A Case for Masvingo Province
}

\author{
Stephen Mago(PhD) \\ University of Fort Hare, P.O Bo X1314, Alice, South Africa \\ Email: stepmago@gmail.com
}

Sibert Chitokwindo

Agricultural Banking Corporation (Agribank), Hurudza House, 5680 Hughes St P.O. Box 211, Masvingo, Zimbabwe

\section{Doi:10.5901/mjss.2014.v5n9p221}

\begin{abstract}
The purpose of this article is to examine the impact of mobile banking on financial inclusion in Zimbabwe. Financial inclusion is an urgent issue because of great numbers of 'unbanked' people in developing countries. The unemployed and low income people find themselves excluded from financial services offered by financial institutions due to access barriers. The paper adopts a qualitative research methodology and a survey design. The survey covered Masvingo district in Zimbabwe. Literature sources were also used to strengthen the field survey findings. The results revealed that the low income people are willing to adopt mobile banking and the reasons are that it is easily accessible, convenient, cheaper, easy to use and secure. Recommendations made are that there is need for the Central bank to supervise non-bank led mobile banking models and manage their cash holding limits and cost structures. The poor people have been traditionally located in the informal sector where they hardly enjoy banking services. With mobile banking, they can now enjoy the same basket of financial services through mobile banking. The mobile banking system is definitely ideal for the remote areas given that it is an easily accessible, cheaper, more convenient and faster means of sending and receiving money. Financial activity is increased in the rural areas and therefore economic growth is boosted.
\end{abstract}

Keywords: Mobile banking, Microfinance, Financial Inclusion, Financial exclusion, 'unbanked' Zimbabwe.

\section{Introduction}

"Mobile phones affect the lives of billions of people around the globe, including the poor. The changing mobile technology has revealed opportunities and allowed nearly three billion people without bank accounts" (Oluwatayo, 2012:53) to access financial services.

The lack of opportunities to access financial services by vulnerable and poor groups has motivated innovation by financial institutions in a variety of ways and that includes the concept of mobile banking. Mobile banking can reach the previously 'unbanked' low income earners and the unemployed as long as they have access to a cell phone.

"While innovations in microfinance have taken centre stage in efforts to expand financial access over the last two decades, attention is now shifting to opportunities to reform formal banking systems to open up savings, loan and insurance products to the financially excluded"(Karlan and Morduch, 2009 cited in Hanohan and King, 2012:2). The significance of mobile banking in this regard is that it brings financial services to the previously 'unbanked' areas hence financial inclusion. According to Ismail and Masinge (2011:1), "despite the obvious potential benefits of mobile banking, questions remain about whether low-income customers will adopt the relatively new technology at a scale sufficient to make it worth offering." This question is still relevant for this present paper.

\section{Background of the Paper}

Access to financial services has always been difficult for the vulnerable groups, that is, low income earners and the unemployed the world over. These groups have become excluded from participating in the financial sector as financial institutions compete and end up closing some remote branches due to viability challenges making those areas no go areas for financial institutions (Mayo et al., 1998). Agarwal (2010:2), quoted Kofi Annan (the the former UN Secretary- 
General) who said,

the stark reality is that most poor people in the world still lack access to sustainable financial services, whether it is savings, credit or insurance. The greatest challenge before us is to address the constraints that exclude people from full participation in the financial sector. Together, we can and must build inclusive financial sectors that help people improve their lives.

The statement reflects that there is consensus on the need to innovate and come up with products that do not discriminate against the poor.

Financial inclusion is a situation where financial services are accessible to low income people. Vulnerable groups are usually excluded due to access barriers. Rani (2006:2) says,

financial inclusion denotes delivery of financial services at an affordable cost to the vast sections of the disadvantaged and low income groups. The various financial services include credit, savings, insurance, payments and remittance services. The objective of financial inclusion is to extend the scope of financial services of the organized financial system to include within its ambit people with low income.

The use of mobile money has advantages of reducing the risk of dealing with cash and provides wide coverage through the use of a communications infrastructure that is used by millions of people (Jenkins, 2008). The risks that are common when using cash are loss due to theft, and for those that remit cash through third parties such as friends or bus drivers, there are chances of the cash not reaching the intended beneficiary. These informal means of transacting result in considerable delays which is a cost through lost time. In an effort to provide financial access to every citizen, the financial authorities (Central Bank and Ministry of Finance) are driving the call for banks, other financial institutions and all stakeholders to come up with innovative products that are affordable to all. Hannig and Jansen (2008:2) say, "financial services to the 'unbanked' have become a major area of interest for policymakers, practitioners, and academics who increasingly emphasize financial inclusion as a policy objective".

In the United States of America, an introduction of the Community Reinvestment Act (CRA) by the Government is often cited as a major initiative to combat the issue of 'unbanked' households. There has been positive impact in that lending to black and Hispanic Americans is higher within CRA regulated areas and that there has been crowding out of lenders falling outside the regulatory powers of the CRA in low income communities (Kempson et al., 2004).

In Australia, the Government partially sold Telstra (the telecommunication company) to raise $A \$ 70$ million to provide banking and other transaction services to communities without banking facilities through the Rural Transaction Centre (RTC) set up in post offices, stores or stand alone facilities run by Councils (Kempson et al., 2004). The programme has benefited 100 communities and many more are applying for funding of the same product.

Financial inclusion has been an issue for many developing countries. Countries such as India, Brazil, South Africa and Kenya have adopted mobile banking, to give banking access to the unbanked sector. In Kenya, a product called MPesa was launched in 2007. According to Mbiti and Weil (2011:1),

M-Pesa is a money transfer system operated by Safaricom, Kenya's largest cellular phone provider which allows users to exchange cash for 'e-float' on their phones, to send e-float to other cellular phone users, and to exchange e-float back into cash. This product has been adopted by citizens from all walks of life and has reached the previously excluded poor. The product has a wide coverage due to the fact that it is used through the mobile phones which are now in possession of many people including the rural folks.

In South Africa, the Mzansi brand is a National banking initiative, launched in 2004 for banks to offer low cost accounts in order to make banking affordable to the majority of the people (Kotler, 2010). Other banks like Standard Bank have introduced the branchless concept where they have replaced brick and mortar with Automated Teller Machines (ATMs) and other electronic channels. One barrier has been the charges that banks levy on account holders which the low income earners cannot afford and Standard Bank South Africa has introduced the Mzansi Blue Account as a solution for the low income market (Kotler, 2010).

In Zimbabwe, the Reserve Bank has been on the forefront urging financial institutions to adopt strategies meant to promote financial inclusion. The Reserve Bank of Zimbabwe (RBZ)'s (2006) Monetary Policy Statement affirmed that the majority of Zimbabweans has no access to financial services. A study by FinMark (2012) revealed that $65 \%$ of the Zimbabwean population stays in the rural area and that only $5 \%$ of rural people have access to a bank which is within 30 minutes reach. A Framework for Financial inclusion was put in place by the Reserve bank, the banking industry and other stakeholders. The thrust of the framework is to encourage banks to be accessible by 'unbanked' poor societies by 
opening rural branches or harnessing technology to come up with products that are accessible and affordable to the majority. The RBZ has taken a keen interest in financial inclusion and has continually, through monetary policy pronouncements, urged banks and financial institutions to be innovative and embrace the financially excluded. This is commendable as the financial activity in these areas will stimulate development through the provision of finance for economic activities.

Some institutions have been innovative and have put in place products and services that are aimed at affording the 'unbanked' sector a chance to participate in one way or the other. Econet Wireless, [currently Zimbabwe's largest provider of telecommunication services in terms of subscribers(around 4 million) (http://www.econet.co.zw)] launched Ecocash, a local money transfer product on 30 September 2011. Zimbabwe has a largely 'unbanked' informal trade sector and rural populace which Econet is also targeting. The introduction of the Ecocash product into the Financial Services sector is expected to bring convenience and access to banking services to the population at large. The fact that Ecocash money transfers are possible through all the three cellular network providers gives every cell phone holder equal opportunity to use the product. In October, 2013, Ecocash launched a new product known as EcocashSave(Herald, October, 2013). The product is housed under Econet's new bank called Steward Bank(formerly TN Bank). According to Steward Bank's Chief Executive, "Steward Bank has brought banking to the unbanked," (Herald, October, 2013:1).

NetOne has the One-Wallet product which is run on its mobile platform and is limited to FBC bank clients. Telecel and Kingdom bank introduced the Skwama mobile banking product which allows its subscribers to use their cell phones to buy air time, pay bills, withdraw cash, transfer and deposit money. The Skwama mobile banking service allowed people to bank in remote areas that have network coverage using their cell phones (Kabweza, 2012). However, this service has disappeared from the market. According to Kabweza(2012), "it has died a natural death."

Through competition, banks are set to harness the rural populace into the banking network through various bank products tailor made to be accessible and affordable to the low income earners.

Kingdom bank has its cell card product, where customers are alerted through their cell phone once their account is credited or debited and one accesses the funds through the use of a debit card swiped at an Electronic Funds Transfer at Point of Sale (EFTPOS) machines installed at retail shops in urban and rural centres. The Central Africa Building Society (CABS) has introduced the branchless concept which also uses EFTPOS machines and pensioners can access their monthly payments through this method. The EFTPOS machines are installed at selected rural and urban retail shops on agency basis.

Agribank is forging a strategic partnership with the Zimpost where the bank would introduce the branchless banking concept through selected Zimpost offices in 'unbanked' rural locations and clients will be able to transact using their mobile phones. Agribank is also negotiating with Econet for an agency deal of the Ecocash product given the bank's wide rural branch network.

Zimbabwe banks are partnering with cell phone providers to offer mobile banking and other cell phone companies such as Econet have come up with their own mobile banking product, Ecocash. There is, therefore, concerted effort from the stakeholders to offer banking services to the majority of Zimbabweans regardless of employment status. The cell phone is a gadget that many people now possess - $85 \%$ of the Zimbabwean population owns or has access to a cell phone (FinMark, 2012). Therefore, mobile banking has the potential to be accessed by $85 \%$ of the population, which is a huge impact. These developments in the financial services sector have urged us to carry out this study to evaluate the impact of mobile banking on the concept of Financial Inclusion.

\section{Problem Statement}

The majority of the Zimbabwean population lives in the rural areas (about 65\%) and only $5 \%$ of the rural population have access to banking facilities so the teething problem is that the majority of the population is financially excluded. Mobile banking has been viewed as a solution to financial inclusion and the challenge is to confirm whether mobile banking is the solution to financial inclusion in Zimbabwe. The majority of the Zimbabwean population remains 'unbanked' and some of the factors that have been cited as causing the poor and vulnerable groups not to take banking services are; inaccessibility, inconvenience and high costs. There is, therefore, need to evaluate whether mobile banking provides opportunities for the financially excluded. Some questions still beg for answers. Does mobile banking offer a solution to Financial exclusion? Does mobile banking offer accessibility to affordable banking services?

\section{Research Objectives}

The main objective of the study is to evaluate the impact of mobile banking as a financial inclusion strategy. The sub- 
objectives of the study are to find out whether mobile banking products meet the needs of the vulnerable groups in terms of affordability, convenience and accessibility.

\section{Significance of the Study}

This study is relevant and significant because it deals with a contemporary issue. Financial exclusion has been pointed as one of the major drivers of poverty; hence, financial inclusion is attracting worldwide attention. Poverty alleviation is one of the eight Millennium Development Goals (MDGs) which Zimbabwe seeks to achieve by 2015 (Kanyenze et al 2011). Mobile banking has the potential to be embraced by people of all social groups for as long as one has access to a mobile phone. It is anticipated that the findings will give insights to the policy makers so that they can formulate policies that encourage effort to embrace the 'unbanked' population. The business community will also draw a leaf from the study's findings and put strategies that respond to the opportunities and threats uncovered through the research effort. The public will make informed choices on whether to adopt or reject mobile banking products. Other scholars may use the research findings to identify areas for further studies. Mobile banking has the potential to offer wider markets for financial institutions by reaching to the previously 'unbanked' people. Corporate strategies can be crafted around this new business model for sustainable competitive advantage.

\section{Research Methodology}

The study adopted a qualitative research methodology guided by a survey design. Data collection was done in Masvingo province of Zimbabwe. The sample size for the study was 270 respondents divided into 50 respondents for each district, 50 respondents from informal sector and 20 tertiary students. Four districts were chosen and used as samples to represent the rest of the population in the province. These are Chivi, Bikita, Gutu and Masvingo. Descriptive survey research is defined by Hart (2007:122) as "based on collection of primary data using tools such as questionnaires and interviewing". Neuman (2000:285) defines survey research as "a process in which researchers translate a research problem into questionnaires, then use these with respondents to create data". Therefore the questionnaire used to collect data on m-banking and financial inclusion sought to establish whether $\mathrm{m}$-banking is convenient, cheaper, easier and secure to use. Survey research is defined by Leedy and Ormrod (2010:187) as "involving acquiring information about one or more groups of people -perhaps about their characteristics, opinions, attitudes, or previous experiences-by asking them questions and tabulating their answers." In this vein, people were asked on whether they consider m-banking as beneficial or exploitative. The data collected from the respondents was analyzed to come to a logical conclusion.

\section{Analysis of Results}

Responses have been analysed against each income group to determine opinions on each proposition by the different groups. The results will help evaluate whether mobile banking would be adopted by the low income people who are largely the 'unbanked' and the target of financial inclusion.

\subsection{Impact of Mobile Banking}

The impact of mobile banking was measured by the responses relating to respondents' views on whether m-banking benefits or exploits people. Reasons for their choice were also solicited to provide a deeper understanding of their view point. Respondents were requested to give their opinions on whether mobile banking benefits or exploits people and their responses are presented below. 


\subsubsection{Response on Whether Mobile Banking Benefit or Exploit People}

Figure 1: Impact of Mobile Banking To Users

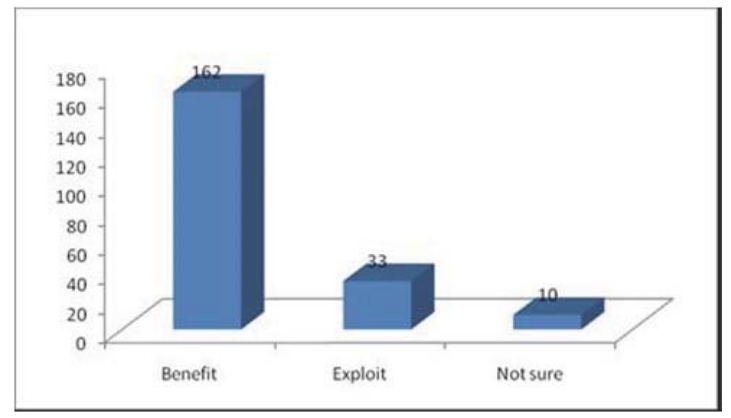

Source: Field Survey (November 2012)

The majority of the respondents $162(79 \%)$ feel mobile banking benefits people whilst $33(16 \%)$ think it exploits people and $10(5 \%)$ were not sure.

\subsubsection{Reasons Why Respondents Feel Mobile Banking Benefit People}

Figure 2: Mobile Banking Benefits

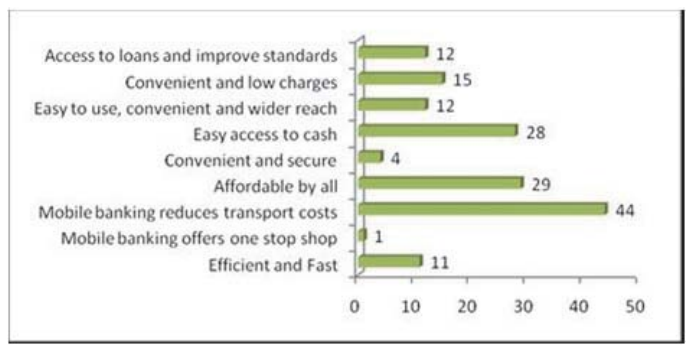

Source: Field Survey (November 2012)

Benefits that were brought up by the respondents include reduced transport costs with 44 respondents, affordability by all with 29 respondents and easy access to cash which had 28 respondents. Convenience and low costs was fourth with 15 respondents. 12 respondents feel mobile banking provides easy use, convenience and wider reach to 'unbanked' areas. Another 12 respondents believe mobile banking benefits are access to loans and improved living standards. At the tail end are 4 respondents who think convenience and security benefits accrue and one respondent believes mobile banking offers a one stop shop benefit.

\subsubsection{Mobile Banking Is Easily Accessible}

Accessibility of financial services by those in remote areas, often rural areas, has been cited as a barrier to financial inclusion. Mahmood and Sahai (2011:203) refer to this as a logistics barrier in that "financial services are not developed in many regions where it is not considered feasible by the service provider". Mobile banking has been found in this research to be considered as easily accessible as shown in the figure 3 below. The issue of accessibility of financial services providers has been a cause for concern for the RBZ which has been calling for banks and Microfinance institutions to open outlets in rural areas so that the 'unbanked' people could join the main stream economy. The figure below shows a cross tabulation of responses on the accessibility of mobile banking by respondents who earn $\$ 300$ and below per month. 
Figure 3: Response by Income Group On Mobile Banking Accessibility

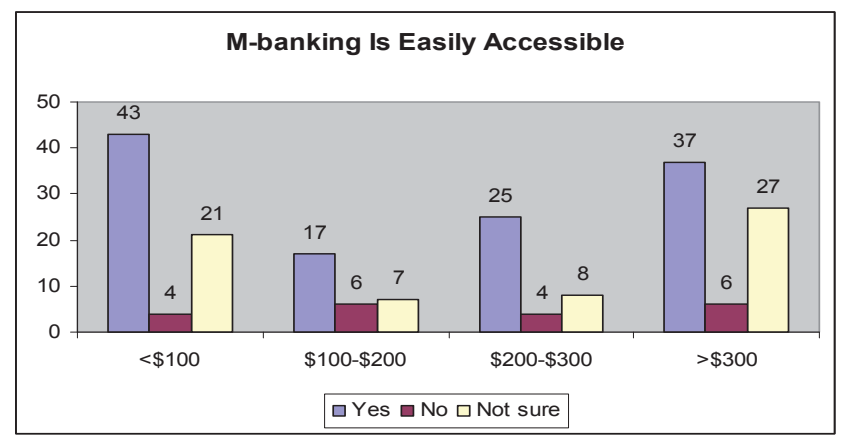

Source: Field Survey (November 2012)

The above figure shows that the majority of people in all income groups believe mobile banking is easily accessible. This is a reflection that mobile banking would be adopted by the majority of people including those in the low income group.

\subsubsection{Mobile Banking Is Easy To Use}

The ability to use a product is key to its adoption and to this end the Gardeva and Rhyne (2011:9) of the Centre for Financial Inclusion stated that " full financial inclusion is a state in which all people who can use them have access to a suite of quality financial services, provided at affordable prices, in a convenient manner, and with dignity for the clients". The issue of ability to use the system has a direct bearing on adoption of the facility. The majority of the research respondents in all income groups indicated that mobile banking is easy to use as depicted in figure 4 . This indicates that more people are ready to adopt mobile banking whenever it becomes available.

Figure 4: Response to Ability to Use Mobile Banking

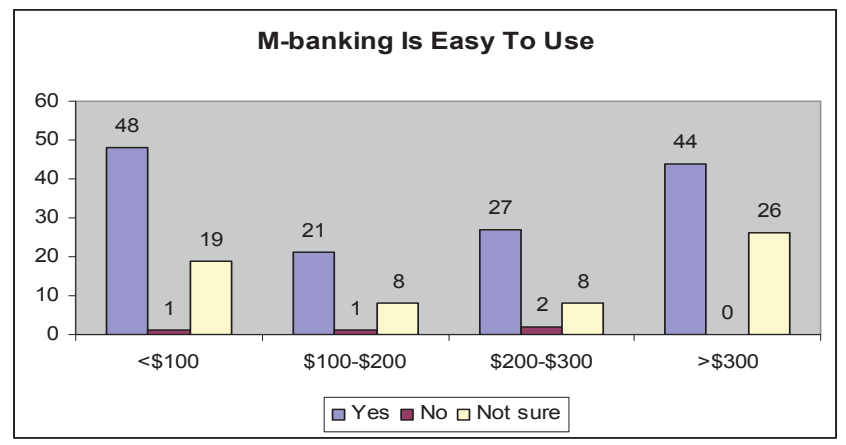

Source: Field Survey (November 2012)

\subsubsection{Mobile Banking Is Secure To Use}

Findings of this research indicate that although the bigger percentage of respondents in all income groups believe $\mathrm{m}$ banking is secure to use, a significant proportion of the respondents were not sure of this proposition. There is need to allay this high level of uncertainty on security of the m-banking product depicted by the number of respondents who are not sure of its security levels. People may shun using m-banking if they feel insecure. 
Figure 5: Response to the question: How Secure is Mobile Banking?

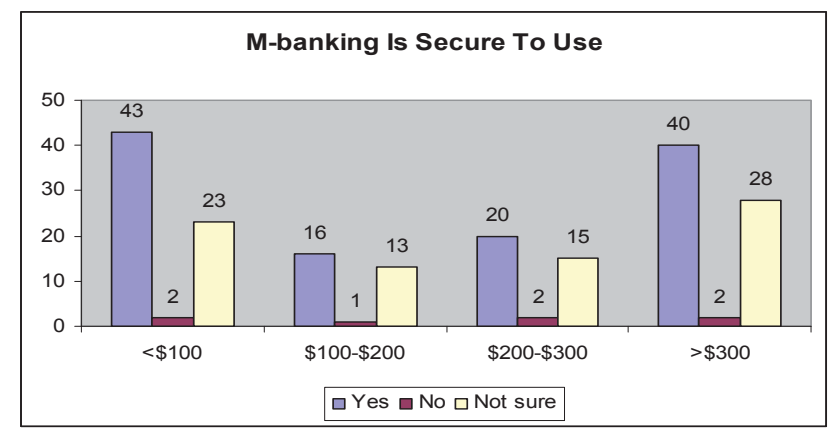

Source: Field Survey (November 2012)

\subsubsection{Response on Comparative Costs of Mobile Banking}

Cost is cited as a barrier to accessing financial services by low income people. Banks levy clients with a variety of charges that include transaction fees on cash withdrawals and deposits, statement and balance enquiry and monthly ledger fees. This has been termed price exclusion (Kempson et al 2004). Findings reveal that most people feel m-banking is cheaper than traditional banking systems. One of the reasons that have been cited is the zero deposit required to maintain a non-bank led m-banking account which only charges transaction fees. There is still a high level of uncertainty on this phenomenon as reflected by the number of respondents who were not sure whether m-banking is a cheaper product as shown in table 1 below.

Table 1: Response to Proposition That Mobile Banking is Cheaper

\begin{tabular}{|c|c|c|c|c|}
\hline Response & $<\mathbf{\$ 1 0 0}$ & $\mathbf{\$ 1 0 0 - \$ 2 0 0}$ & $\mathbf{\$ 2 0 0 - \$ 3 0 0}$ & $>\mathbf{\$ 3 0 0}$ \\
\hline Yes & $53 \%$ & $63 \%$ & $43 \%$ & $44 \%$ \\
\hline No & $12 \%$ & $7 \%$ & $14 \%$ & $7 \%$ \\
\hline Not sure & $35 \%$ & $30 \%$ & $43 \%$ & $49 \%$ \\
\hline
\end{tabular}

Source: Field Survey (November 2012)

\subsubsection{Response to the Proposition That Mobile Banking Is Convenient To use}

The results show that respondents in all income groups feel that $\mathrm{m}$-banking is convenient to use as shown in figure 6 . $\mathrm{M}$ banking is accessible 24 hours on a daily basis thus providing convenience.

Figure 6: Response to the Proposition That Mobile Banking Is Convenient

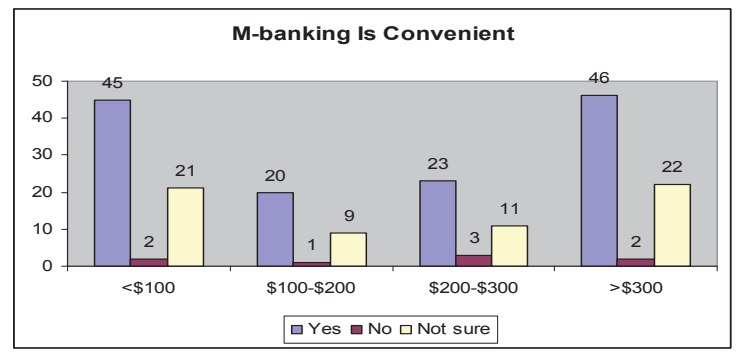

Source: Field Survey (November 2012) 


\subsubsection{Financial Deepening}

Mobile banking has the ability to reach the 'unbanked' sectors of the economy (Klein and Mayer, 2011), for as long as there is mobile connectivity and the capturing of this market increases the participants in the financial services sector. Financial inclusion refers to the access of affordable financial services by the previously excluded low income and vulnerable groups (Agarwal 2010). Through mobile banking, it provides greater financial intermediation of the economy as a whole or financial deepening which then drives demand. Technology then facilitates distribution of financial resources to previously excluded areas thereby stimulating economic growth (Gonzalez-Vega, 2003, Drabu 2009; Altay and Atgur 2010). The adoption of m-banking by the 'unbanked', who are the majority, according to empirical evidence, will lead to improvement and growth of the financial market in the country. Therefore it can be inferred that this will lead to economic growth based on the financial deepening hypothesis (Karahan and Yilgor, 2011; Fritz, 1984). Figure 7 shows the responses on impact of mobile banking in terms of benefits derived from it and whether people are exploited by it.

Figure 7: Response to Whether Mobile Banking Benefits or Exploits People

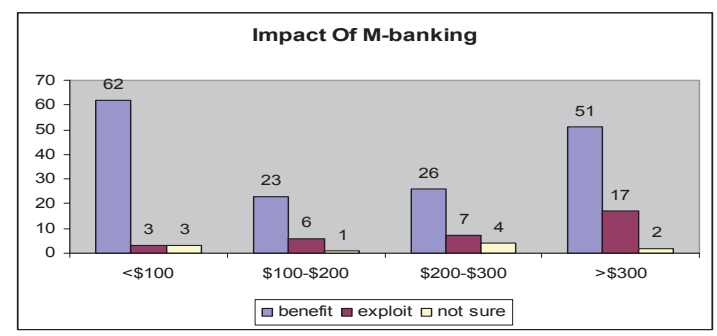

Source: Field Survey (November 2012)

Given that the majority of respondents in all income groups indicate that mobile banking benefit people, it can be concluded that $\mathrm{m}$-banking will be adopted by the majority of people. The adoption of $\mathrm{m}$-banking by the majority will result in financial inclusion which in turn promotes economic activity and thus economic growth.

\subsubsection{Reasons Why Respondents Feel Mobile Banking Exploit People}

Figure 8: Mobile Banking Disadvantages

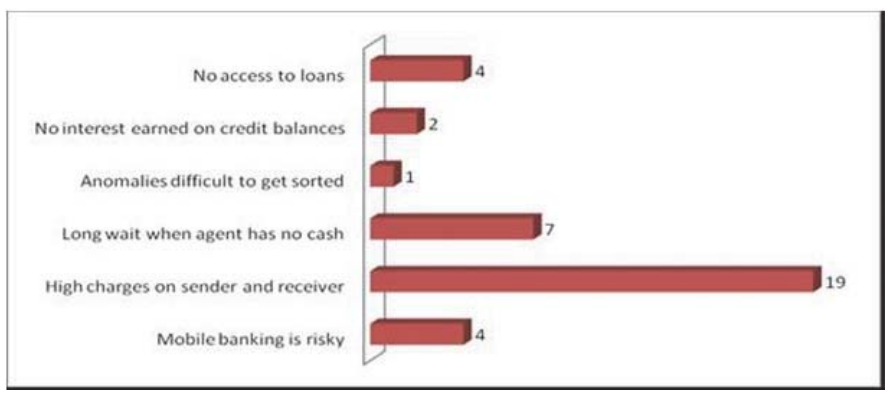

Source: Field Survey (November 2012)

Figure 8 shows reasons why respondents consider mobile banking exploit people. The majority in this group are 19 respondents who feel mobile banking charges are high as both sender and receiver are charged. 7 respondents cited long waiting periods when agents do not have cash. 4 respondents believe mobile banking is risky whilst another 4 cited lack of access to loans. 2 respondents feel mobile banking exploits people because there is no interest earned on credit balances. One respondent cited that anomalies on remittances are difficult to get resolved. 


\section{Conclusion and Recommendations}

The use of mobile banking has been examined in this research and it has been exposed that sending and receiving money is the most popular function followed by buying of airtime. This reflects the fact that mobile banking is filling a gap that has been in existence for a long time and has taken a distinct function which has traditionally, been the preserve of banks- custody of the national payment system. The low income people who traditionally have been relegated to the informal sector can now enjoy the same basket of financial services through mobile banking. The non-bank led mobile system is definitely ideal for the remote areas given that it is easily accessible, cheaper, convenient and a faster means of sending and receiving money. Financial activity is increased in the rural areas and therefore economic growth. According to Levine (2005), Financial Sector Development(FSD), representing financial activity, has direct impact on economic growth and development and ultimately poverty reduction. Honohan(2004) also explained a similar relationship between financial development and economic growth. Figure 9 below illustrates the impact of FSD on poverty reduction through economic growth.

Figure 9: Impact of FSD on Growth and Poverty Reduction.

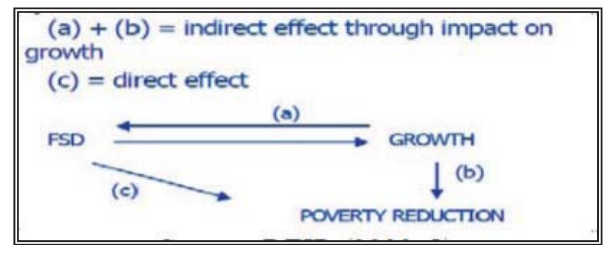

\section{Source: DFID(2000:5)}

The mobile banking concept is in its infancy in Zimbabwe, and as such, its full impact to the economy is yet to be realised and therefore the Government must ensure that a separate regulatory authority is set up to effectively manage this subsector which has potential to be a very high volume financial transaction platform. This poses potential risk that mobile banking may over step and overtake some commercial banking functions. There is therefore need to regulate and confine it to its main objective of remittances. The Government should also make it mandatory for all mobile network companies to participate in this product to reduce costs for consumers.

The Central bank must urgently come up with regulations that ensure that all mobile banking transactions are tracked to avoid huge cash balances 'floating' outside the formal system which then threaten liquidity in the economy. Banks must come up with deliberate policies that allow them to be intermediaries or agents for the non-bank led product which has deeper access to people in order to lubricate the cash constraints and make the product more convenient. The mobile phone operators must come up with ways of empowering all cell phone users by ensuring that mobile banking functions are made easier but secure to operate so that more people are motivated to use the product.

\section{References}

Agarwal, A.(2010). Financial Deepening: Financial Inclusion, Challenges and Opportunities, $23^{\text {rd }}$ Skoch Summit.

Altay, O. and Atgur, M. (2010). VAR Model Approach to the Financial Deepening and Economic Growth Relationship in Turkey During The Period (1970-2006): Paper Presented at Statistik Arastimma Sempozyumu, Ankara, Turkey.

Drabu, H. A. (2009). Financial Inclusion: Economics and Inclusion, Academic Foundation. India

FinMark (2012). FinScope Consumer Survey Zimbabwe 2011. [Online] Available: www.zimstast.co.zw/dmdocument/Finance/Launch.pdf (September 17, 2013).

Fritz, R. (1984). Time Series Evidence of the Causal Relationship Between Financial Deepening and Economic Development, University of Central Florida. USA.

Gardeva, A. and Rhyne, E. (2011). Opportunities and Obstacles To Financial Inclusion. Center for Financial Inclusion Publication number 12.

Gonzalez-Vega, C. (2003). Deepening Rural Financial Markets: Macroeconomics, Policy and Political Dimensions, The Ohio State University. USA.

Honohan, Patrick. (2004). "Financial Development, Growth and Poverty: How Close Are the Links?" World Bank Policy Research Working Paper 3203.Washington: World Bank (February).

Hanohan Patrick and Michael King. (2012). Cause and effect of financial access: Cross-country evidence from the Finscope Surveys. 
IIIS Discussion Paper No. 399. [Online] Available: http://michaelking.ie/wp-content/uploads/2011/11/Honohan-and-King-Causeand-Effect-of-Financial-Access-April-2011-3.pdf (October 14, 2013).

Hannig, A. and Jansen, S. (2010). Financial Inclusion and Financial Stability: Current Policy Issues. ADBI Working Paper Series, No. 259. ADB Institute.

Hart, C. (2007). Doing Your Masters Dissertation, Sage Publications. London

Ismail, T. and Masinge, K. (2011). Mobile banking: Innovation for the poor, Working paper series \#2011-074, United Nations University.

Jenkins, B. (2008). Developing Mobile Money Ecosystems, Washington, DC. IFC And The Harvard Kennedy School.

Kanyenze, G., Kondo, T., Chitambira, P., and Martens, J. (2011). Beyond the Enclave, Towards a Pro-Poor and Inclusive Development Strategy for Zimbabwe. Weaver Press, Harare.

Karlan, D. and Morduch, J. (2009). "Access to Finance" in Dani, R and Rosenzweig, M (eds), Handbook of Development Economics, Volume 5: 4704-4784. Amsterdam: Elsevier.

Karahan, O. and Yilgor, M. (2011). Financial Deepening and Economic Growth in Turkey, Balikesir University.

Kempson, E., Atkinson, A. and Pilley, O. (2004). Policy Level Response to Financial Inclusion In Developed Economies: Lessons For Developing Countries, University of Bristol.

Klein, M. and Mayer, C. (2011), Mobile Banking and Financial Inclusion, The Regulatory Lessons. The World Bank Policy Research Working Paper 5664

Kotler, P. (2010). Principles of Marketing, Southern Region Perspective, Prentice-Hall, Europe.

Kabweza L.M.S. (2012). Telecel reveals they killed off the Skwama mobile money service. [Online] Available http://www.techzim.co.zw/2012/09/telecel-reveals-they-killed-off-the-skwama-mobile-money-service/\#sthash.fSMIGkrV.dpuf. (January 27, 2014.

Leedy, P. D. and Ormrod, J.E. (2010). Practical Research, Planning and Design. Pearson

Levine, Ross. (2005). "Finance and Growth: Theory and Evidence." In Handbook of Economic Growth, vol. 1A, edited by Philip Aghion and Steven N. Durlauf, chapter 12. Amsterdam: Elsevier.

Mahmood, I. and Sahai, S. (2011). Profitable Models for Financial Inclusion, State Bank Staff

Mayo, E., Conaty, P., Doling, J., Mullineux, A.(1998). Small is Bankable: Community Reinvestment in theUK, New Economic Foundation, London.

Mbiti, I. and Weil, D.N. (2011). Mobile banking: The Impact of M-Pesa In Kenya. http:/www.nber.org/papers/w17129, accessed 20111208.

Neuman, W. L. (2000). Social Research Methods; Qualitative and Quantitative Approachesnumber1/article6.pdf

Odhiambo, N. M. (2011). Financial Deepening, Capital Inflows and Economic Growth Nexus in

Of Farming Households In Rural Southwest Nigeria. International Journal of Computing and ICT Research, Vol. 6 Issue 1, pp 52-59. [Online] Available: http://www.ijcir.org/volume6- (November 10, 2013).

Oluwatayo, Isaac B.(2012). Mobile Phones as Mobile Banks and Credit Outlets: The Experiences of Farming Households in Rural Southwest Nigeria. International Journal of Computing and ICT Research, Vol. 6 Issue 1, pp 52-59. [Online] Available: http://www.ijcir.org/volume6-number1/article6.pdf. (October 14, 2013).

Rani Martina. (2006). Indian Mobile Banking: A Tool of Financial Inclusion. Accessed: Regulatory Lessons. The World Bank Policy Research Working Paper 5664; Reinvestment In The UK, New Economic Foundation, London.

Reserve Bank of Zimbabwe. (2006). Monetary Policy Statement.

The Herald. (October, 10 2013). EcoCash launches new banking product. [Online] Available: http://www.herald.co.zw/ecocashlaunches-new-banking-product/ (January 27, 2014). 